\title{
Cogon Grass As an Alternative Fibre for Pulp and Paper-Based Industry: On Chemical and Surface Morphological Properties
}

\author{
Angzzas Sari Mohd Kassim ${ }^{1, a}$, Ashuvila Mohd Aripin ${ }^{2, b}$, Nadiah Ishak ${ }^{1, c}$, \\ Muhd Hafeez Zainulabidin ${ }^{3, \mathrm{e}}$ \\ ${ }^{1}$ Faculty of Technology Engineering, Universiti Tun Hussein Malaysia, 86400 Parit Raja, Batu \\ Pahat, Johor, Malaysia \\ ${ }^{2}$ Faculty of Science, Technology and Human Development, Universiti Tun Hussein Onn Malaysia, \\ 86400 Parit Raja, Batu Pahat, Johor, Malaysia \\ ${ }^{3}$ Faculty of Mechanical and Manufacturing Engineering, Universiti Tun Hussein Onn Malaysia, \\ Malaysia
}
aangzzas@uthm.edu.my, bashuvila.aripin87@gmail.com, nadiah.ishak89@gmail.com, ehafeez@uthm.edu.my

Keywords: Cogon grass, chemical properties, green technology, surface morphology, sustainable

\begin{abstract}
The increasing demand in wood fibre consumptions especially in pulp and paper making has pushed forward the search for alternative fibre resources. Non-wood derived fibre could be good candidates due to its abundance availability. Agriculture residues or non-wood annual plants are good potential fibre resource for pulp and paper making. The objective of this study is to determine the suitability of cogon grass as an alternative fibre for pulp and paper making by analysing its chemical and surface morphological properties. The cellulose, hemicelluloses, lignin, $1 \% \mathrm{NaOH}$ solubility, hot water solubility and ash contents were quantified to analyse its chemical characteristics. Quantification of chemical compositions was conducted in accordance with relevant Technical Association of the Pulp and Paper Industry (TAPPI) Tests, Kurscher-Hoffner and Chlorite methods. Scanning electron microscopy (SEM) was used to visualize the surface morphology of the cogon grass fibre. Results obtained indicate that the cellulose $(37.13 \%)$ and hemicellulose $(27.13 \%)$ content is comparable with other published non-woods and the lignin $(5.67 \%)$ content is favourably the lowest. In addition, the hot water and $1 \% \mathrm{NaOH}$ solubilities are $(3.83 \%)$ and $(19.64 \%)$ respectively. SEM images show that cogon grass fibres contained abundance and long fibres which provide good strength of the produced handsheet. Based on the chemical and surface morphological properties analyses, cogon grass is a good alternative fibre resource especially for pulp and paper-based industries.
\end{abstract}

\section{Introduction}

The worldwide consumption of pulp and paper products has tremendously increased due to the population growth, development of communication and industrialization in many developing countries [1]. Conventional pulp and paper production utilizes fiber from wood has inevitably resulted in the depletion of wood resources. Therefore, it is of the main concern and interest to seek for alternative fiber resources derived from non-wood plants. Non-wood fibres offer several advantages including its abundance volume, a short cycle growth, cheaper cost of production and environmentally friendly [2].

Cogon grass (Imperata cylindrical L.), belongs to the Poaceae (Gramineae) grass Family and also name as jap grass, blady grass, spear grass, alang-alang and lalang [3]. This grass is known as a disruptive grass species found throughout the tropical and subtropical areas of the world [4, 5]. In addition, cogon grass ability to spread and replaced desirable vegetation outweighed any soil erosion considerations [6]. Moreover, the rough edges of mature cogon grass leaves and silica bodies throughout the leaves cause mammals to avoid chewing the foliage [6] and make it unsuitable for grazing animals. In Malaysia, cogon grass is abundant along roadside and open areas where it shows aggressive growth. This is due to its ability to survive in dry, unproductive areas 
where other plants have difficulties because of the good root systems that are able to extract water and minerals from the soil. Normally, cogon grass plants are about 1 meter tall and the leaf margins are translucent and rough [6]. Due to the short growth cycle, unsuitability for grazing animal and lack of applications of the cogon grass, hence it could be proposed to be used as an alternative pulp for paper making to replace the origin resource of wood. In the long run, it also could reduce deforestation and other environmental problems related with processing of wood pulps.

Therefore, this study is investigating the suitability of cogon grass as an alternative fibre for pulp and paper production based on the analyses of its chemical and surface morphological properties.

\section{Material and Methods}

\section{Materials}

Cogon grass samples were collected from Taman Universiti, Parit Raja. Prior to air-dried, these plants were cut into $2-5 \mathrm{~cm}$ in length and were thoroughly washed to eliminate sand and other contaminants. For the chemical analyses, the air-dried samples were ground to $0.40-0.45 \mathrm{~mm}$ and stored in an air tight container for further analyses.

\section{Methods}

Chemical compositions characterization. Chemical compositions of cogon grass were performed according to Technical Association of the Pulp and Paper Industry (TAPPI) Test Method. The samples were first submitted to soxhlet extraction for 6 hours according to method T 264 om-88. The evaluation of extractive substances was carried out in different liquids according to experimental parameters: hot water (T $207 \mathrm{~cm}-08)$ and 1\% NaOH solution (T $212 \mathrm{om}-07)$. The ash content ( $\mathrm{T} 211 \mathrm{om}-07$ ) also was determined. The amount of lignin, hemicelluloses and cellulose were assessed by using the following respective standard methods: T 222 om-06, Chlorite Method and Kurschner-Hoffner approach. All experiments were conducted in triplicates.

Surface morphology characterization. The surface morphology of cogon grass was visualized in a JEOL JSM-6380LA analytical Scanning Electron Microscopy (SEM). The materials were treated with $8 \% \mathrm{NaOH}$ to remove impurities and placed in a vacuum dry oven at $60^{\circ} \mathrm{C}$ overnight. A small piece of specimen $\left(0.5 \mathrm{~cm}^{2}\right)$ was placed onto a double-sided tape of the specimen stub. The specimen was lightly pressed by a release paper and coated with a thin layer of gold-palladium film before it was submitted to SEM for visualization of the fibre surface morphology characteristic.

\section{Results and discussions}

Chemical compositions characterization. Table 1 shows the overall mean of the chemical compositions of cogon grass fibre. However, the cellulose content in cogon grass is $37.13 \%$, higher than the vine stems, which has proven to be a successful alternative fibre for pulp and paper-based [7]. In pulp and paper industry, cellulose is an important constituent in paper making because the higher content of cellulose produces a higher quality and stronger paper. The high cellulose content in cogon grass is advantageous as higher pulp yield will be obtained after the cooking process. The cogon grass is characterized by relatively low hemicellulose content compared to non-wood resources and relatively close to wood resource (Eucalyptus globulus) as shown in Table 1. This amount could contribute to the strength of pulp and paper product [11]. Moreover, the lignin content in cogon grass $(5.67 \%)$ was the lowest than the published non-woods $(20-28 \%)$ as well as woods fibre (19.9 - 26.2\%). Lignin is considered to be an undesirable polymer that is removed during pulping process [12]. Lower lignin content indicate lesser chemicals needed during the 
pulping and bleaching processes [13] and ultimately reducing both the energy needed for processing and the hazardous chemical wastes released to the environment.

The $1 \% \mathrm{NaOH}$ solubility content is the lowest in cogon grass $(19.64 \%)$ compared to vine stems (37.8\%) [7]. Low solubility indicates less fibre degradation during the chemical pulping process and thus the pulp yield would be high [14]. Moreover, the hot water solubility content in cogon grass $(3.83 \%)$ is slightly higher than wood plants $(2.0-2.8 \%)$ [10] but very much lower compares to other the non-wood vine stems (13.9\%) [7]. Lower hot water solubility content will also yield higher pulp content after the pulping process. Finally, the ash content obtained in cogon grass $(8.24 \%)$ is higher than other non-woods $(3.9-6.7 \%)$ and wood $(0.5-0.6 \%)$ as seen in Table 1. High content of ash could contribute to low pulp yield [13], however, to analyse the suitability of cogon grass as an alternative fibre, overall parameters of chemical and physical compositions of the fibre and handsheet produced have to be taken under consideration.

Table 1: The chemical compositions of cogon grass and other published non-wood and wood fibres

\begin{tabular}{|l|c|c|c|c|c|c|}
\hline \multirow{2}{*}{$\begin{array}{c}\text { Chemical properties } \\
(\% \mathrm{w} / \mathrm{w})\end{array}$} & \multicolumn{4}{|c|}{ Raw-wood fibre } & \multicolumn{2}{c|}{ Wood fibre } \\
\cline { 2 - 7 } & $\begin{array}{c}\text { Cogon grass } \\
\text { [This study] }\end{array}$ & $\begin{array}{c}\text { Vine } \\
\text { stems [7] }\end{array}$ & $\begin{array}{c}\text { Cynara } \\
\text { Cardunclus } \\
\text { L. [8] }\end{array}$ & $\begin{array}{c}\text { Canola } \\
\text { straws } \\
{[9]}\end{array}$ & $\begin{array}{c}\text { Eucalyptus } \\
\text { globulus } \\
{[10]}\end{array}$ & $\begin{array}{c}\text { Pine } \\
\text { pinaster } \\
{[10]}\end{array}$ \\
\hline Cellulose & 37.13 & 35.00 & 40.50 & 48.50 & 53.00 & 55.90 \\
\hline Hemicellulose & 27.13 & 30.40 & 32.00 & 29.00 & 27.50 & 14.10 \\
\hline Lignin & 5.67 & 28.10 & 25.40 & 20.00 & 19.90 & 26.20 \\
\hline $1 \%$ NaOH solubility & 19.64 & 37.80 & n.a & n.a & 12.40 & 7.90 \\
\hline Hot water solubility & 3.83 & 13.90 & 11.50 & n.a & 2.80 & 2.00 \\
\hline Ash & 8.24 & 3.90 & 6.70 & 6.60 & 0.60 & 0.50 \\
\hline n.a: non-available & \multicolumn{7}{|c|}{} \\
\hline
\end{tabular}

Surface morphology characterization. The surface morphology analysis was carried out by Scanning Electron Microscopy (SEM). Figure 1 displays the SEM images of cogon grass observed under different magnification levels. The study on surface morphology was significant in understanding the distribution and arrangement of the plant fibre.

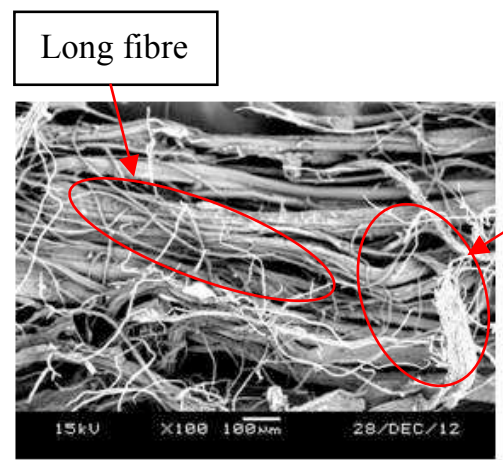

(a)

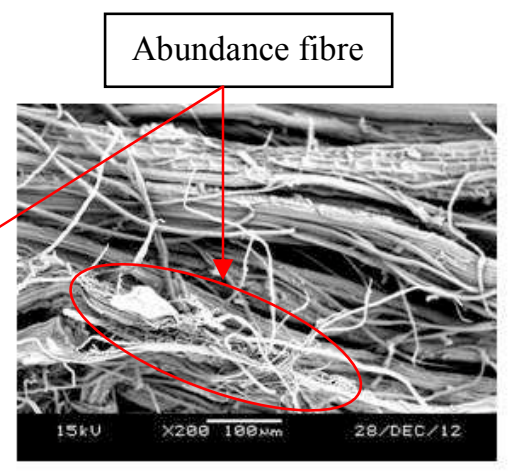

(b)

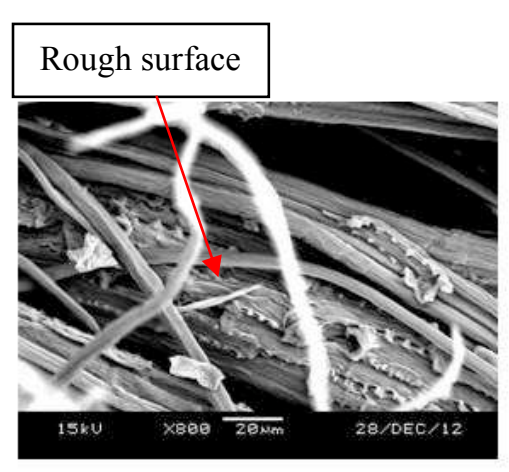

(c)

Figure 1: SEM images of cogon grass on magnification level at: (a) 100x, (b) 200x and (c) 800x

The fibre morphology of cogon grass consists of abundance and long fibres (more than 1.2 $\mathrm{mm}$ ) as seen in Fig. 1(a) and (b). The long fibres in cogon grass will produce high strength of handsheet due to the compact interfibre link during the paper-based process. Fig. 1 (c) shows that 
the fibre consists of rough of surfaces that protect the lignocellulosic content in this fibre. As previously explain, cogon grass has high content lignocellulosic that are shown in Fig. 1 (a) and (b) with linear fibrillar arrangements.

\section{Conclusions}

This study revealed that the cellulose and hemicellulose content of cogon grass are comparable to other published non-wood and wood fibre resources that have been successfully used in pulp and paper-based processes. The lignin content indicates that cogon grass fibre presented the lowest than all other non-wood and wood resources whereas the $1 \% \mathrm{NaOH}$ and hot water solubilities are considered low and comparable to other published wood plants. Finally, the SEM images of cogon grass fibre indicate that it has compact, abundance and long fibre that will provide high strength of the handsheet produced. Based on the chemical compositions and surface morphological studies, cogon grass fibre is a suitable candidate as a non-wood alternative fibre for pulp and paper making.

\section{Acknowledgements}

This research was financially supported by the Ministry of Education and a scholarship from UniversitiTun Hussein Onn Malaysia (UTHM). The authors are thankful for this financial support.

\section{References}

[1] A.A Enayati, Y.Hamzeh, S.A. Mirshokraie and M. Molaii. BioResources. 4(1) (2009) 245256.

[2] M.S. Jahan, I.M. Khalidul, C.D.A. Nasima, M.S.M. Iqbal and U. Arman. Ind. Crop Prod. 26 (2007) 259-264.

[3] H. Dozier, J.F. Gaffney, S.K. McDonald, E.R.R.L. Johnson. and D.G Shilling. Weed Tech. 12 (1993) 737-743.

[4] S.K. McDonald, D.G. Shilling, T.A. Bewick, D. Gordan, D. Hall and R. Smith.Proc. Weed Sci. and Society of America. (1996) 36-46.

[5] J. Wang: Master's Thesis (2008).

[6] N.C. Coile and D.G Shilling. Botany Circular. 28 (1993) 3.

[7] S. Mansouri, R. Khiari, N. Bendouissa, S. Saadallah, F. Mhenni and E. Mauret. Ind. Crop Prod. (2012) 22-27.

[8] A. Antunes, E. Amaral and M.N. Belgacem. Ind. Crop Prod. (2000) 85-91.

[9] R. Hosseinpour, P. Fatehi, L.A. Jahan, N. Yonghao and S.S. Javad. Bioresour. Technol. 101 (2010) 4193-4197.

[10] L. Jiménez, A. Rodríguez, A. Pérez, M. Ana and L. Serrano. Ind. Crop Prod. (2008) 11-16.

[11] M.A. Ashuvila, M.K. Angzzas Sari, D. Zawawi and M.H.M. Zainuri. Inter. J. Integr. Eng. 5(1) (2013) 30-33.

[12] D. Zawawi, M.H.M. Zainuri, M.K. Angzzas Sari, A. Halizah and M.A. Ashuvila. BioResources. 9(1) (2014) 872-880.

[13] D. Zawawi, A. Halizah, M.K. Angzzas Sari, M.H.M. Zainuri and M.A. Ashuvila. Adv. Mater. Res. 911 (2014) 331-335.

[14] R. Hosseinpour, P. Fatehi, L.A. Jahan, N. Yonghao and S.S. Javad. Bioresour. Technol. 101 (2010) 4193-4197. 